\title{
The corporate governance mechanisms: evidence from Tunisian banks
}

\author{
Sana Triki Damak \\ Faculty of Economic Sciences and Management, University of Sfax (Tunisia) \\ UR: COFFIT - FSEG Sfax
}

\begin{abstract}
This study aims to detect the existence of some corporate governance mechanisms in Tunisian banks. It is devoted specifically to check whether the mechanisms provided by the law, board of directors, auditors, Audit Committee and Executive Committee of credit, are used by Tunisian banks provided in the sample and if the majority of these banks opt or not for independent board.

This descriptive study conducted on a sample of eight Tunisian banks over the year 2006, confirms that most of the mechanisms used by banks are the ones imposed by laws and regulations, all banks in the sample have a board of directors, an auditor, a permanent audit committee and an executive committee. Credit Tunisian banks are increasingly opting for a more independent board of directors. Finally, we note the importance of internal mechanisms versus external ones.
\end{abstract}

Keywords: audit committee, auditors, board of directors, corporate governance, executive credit committee, Tunisian banks

\section{INTRODUCTION}

The topic of corporate governance has become central to any reflection on the company. The debate in this area has extremely grown both nationally and internationally after a series of scandals involving not only large companies in which they occur, but a whole system of managing relations between those who manage the business and those who own it. These scandals, such as Enron in the United States in 2001, Vivendi Universal in France in 2002, Parmalat in Italy in 2003..., would never have existed if the businesses were sole proprietorships or family, because in these two types of businesses, managers are always oriented towards the interests of owners, it is not likely to be in situation of conflicts of interest. However, due to the growth of companies and the introduction of foreign capital, conflicts of interest could rise between the shareholders owners and managers.

The multiplicity in form of firms and sectors in the economy makes it difficult to develop a uniform thinking on the subject of corporate governance. The banking sector is a delicate field of research that has not been sufficiently considered despite its importance. Referring to Pathan and Skully (2010), the recent global financial and banking crises also highlights the importance of improving understanding of bank governance.

In this context, we focus on the study of governance, in the banking sector; this choice was dictated by three considerations:

Firstly, banks have an important weight in the economy, so their governance concern not only shareholders and managers, but also customers, depositors, creditors,... that's why some authors consider that governance of banks acquires a public interest (Louizi, 2006). Despite the importance of this sector, Adams and Mehran (2003) and Caprio et al. (2007) underline the fact that only few scientific papers treat banking governance.

Secondly, banks are characterized by distinct problems agencies compared to other firms, which are caused primarily by information asymmetry existing between all players in the banking sector. The special nature of banking business requires the implementation of more specific and complex mechanisms for banking governance (Rachdi and Ghazouani Ben ameur, 2011).

Finally, the banking sector is a highly regulated industry, reflecting its importance and concern for the corporate governance. So it is important to verify if mechanisms of governance imposed by laws and regulations are adopted or not by banks.

The study of Erkens et al. (2012) in 296 financial firms from 30 countries provides insight into why some financial firms were much more affected by the 2007-2008 crises than others. Tunisia is a small country with a small financial market which is not in the direct field of wave propagation crisis of the USA in 2007 and 2008. The Tunisian banks were no too much exposed to the financial crisis for the simple reason that the Tunisian financial system follows very specific rules under strict control of the Central Bank of Tunisia (3C etudes, 
$\left.2008^{1}\right)$. The year of real change in the practices of corporate governance in Tunisia was 2006. Indeed, the banking landscape is reinforced in 2006 by a new draft law amending and supplementing the Law of 1958 on the establishment and organization of the Central Bank of Tunisia. Thanks to this legislation, the BCT receives new powers in the areas of consulting, monitoring, control and transparency of the publication of financial and economic information. We chose therefore 2006 as a year of analysis.

We seek specifically to identify governances' mechanisms used frequently in 2006 by Tunisian banks. Exploring the banks, we must take into account its specificities when handling these firms.

We will present in the second section the theoretical basis and mechanisms of corporate governance, our research hypotheses in the third section. In the fourth section, we will proceed with our exploratory study on the Tunisian banks by presenting the sample and the methodology of research. Finally, we will present the results of the study.

\section{THEORETICAL BASIS AND MEChanisMs OF CORPORATE GovernanCE}

The transition from individual ownership to collective ownership has the effect of separation between the functions of ownership and decision-making. This separation, in a context of information asymmetry, leads to opportunistic behavior from the managers.

\section{1) Types of conflict between managers and stakeholders in the firm}

\section{a) Agency conflicts}

The dissociation of functions between managers and shareholders breaks the smooth running of the company. Indeed, in a rational environment, each group seeks to maximize its own profit to the detriment of the other, which is causing conflicts between shareholders and managers.

Several factors have helped the managers to maximize their own profit. We mention particularly the problem of asymmetric information. In fact, managers are usually more informed than shareholders about the nature of the business. At this level, the question of opportunism needs to be evoked.

Opportunism of managers is realized by handling private information and managing their reputation by choosing the projects that generate a maximum of liquidity in the short-terms. The managers may also take advantage from the lack of transparency to communicate only informations that serve their interests. Using this strategy, the managers protect their places from the competition in the labor market of managers. In this context, Stieglitz and Edling (1992) propose a model in which managers augment the investments of the company to increase information asymmetry. Similarly, Morck et al. (1990) found that the manager engages the company in numerous acquisitions to increase personal benefits, even if the consequences of these acquisitions could harm the own value of the company.

\section{b)}

\section{Cognitive conflict}

The officers, directors and significant shareholders may propose or oppose in the assessment of the viability and the success of a project, on the basis of the same information, because they have different cognitive models. In this context, Fransman (1998) distinguishes theories based on "knowledge" (cognitive theories) that consider that firms are directories of knowledge, based on such information. The notion of knowledge is subjective, resulting from the interpretation of information by individuals and their contingent cognitive models.

According to Charreaux (2002), the arguments that led to the emergence of cognitive theory are:

- The orientation of the activity depends on the particular vision of managers.

- The creation of knowledge is the basis of all innovation and investment opportunities.

- The coordination in production activities involves transfer of knowledge. The main coordination problems are due to cognitive conflicts because people don't share the same view.

- The company operates not only to reduce conflicts of interest but also to reduce cognitive conflicts or the ones of ethics and values.

\section{Behavioral conflicts}

Some authors propose to use the behavioral paradigm to construct a more satisfactory alternative theory.

To understand very well the reality of human behavior, Rabin (2002) defines finance behavior as a component economic one, which aims to understand more the financial decisions. It is necessary to protect individuals from the behavioral biases that affect them such as overconfidence, loss aversion and regret, optimism ... which are often attributed to the managers. In this context, Charreaux and Albouy (2005) argue that behavioral biases are an additional source of agency costs. They seek, therefore, to explore the consequences of the behavioral literature on the theory of governance.

\footnotetext{
${ }^{1}$ 3C ETUDES - INSTITUT D'ETUDES MARKETING, MEDIA ET OPINION, « La crise financière « mondiale » : une aubaine pour la Tunisie, les PME en Europe et les véritables valeurs de travail » study conducted in October 2008 on the impact of the financial crisis on the Tunisian banks: http://www.3Cetudes.com/
} 
"Behavioral" bias is usually defined with reference to a standard "Ideal" behavior corresponding to perfect rationality. But individuals are not always perfectly rational (Charreaux, 2005). Behavioral biases are, in this context, a particular source of inefficiency which must be remedied. The inefficiency of behavioral origin must be clearly distinguished, as Ulen (1998) recommended, from the factors related to information asymmetries. In the traditional perspective, behavior biases can be explained by factors related to the environment of the decision, For example, motorists are either insufficiently informed of the risks, or they consider sanctions as insufficient. The action aims to fill the information gaps or to impose strong sanctions. Behavioral perspective offers another explanation: If the drivers do not wear their seat belt is that, for example, they are "overconfident" in their ability to drive.

Following three sources of conflicts, the concept of corporate governance acquires a considerable weight in corporate life. At this level, the concept and mechanisms of governance should be defined.

\section{2) Mechanisms of corporate governance}

Aoki (2000) defines governance as a system to control possible schemas to allocate the information to different participants in the organization. Similarly, Charreaux (1996) defines corporate governance as a set of mechanisms that outline the powers, influence management decisions, "govern" the behavior and limit discretionary space of managers. This is a definition of governance centered on key executives, namely that the governance intended to govern management decisions and define their decision latitude. Finally, Zingales (2000) redefines the role of the governance system such as aligning the ability to seize growth opportunities. In other words, we must "discipline" stakeholders so that the potential for value creation is best achieved.

The system of corporate governance encompasses all mechanisms designed to control managers and reduce conflicts of interest considered expensive. We distinct two types of mechanisms: internal and external mechanisms.

\section{(1) Internal mechanisms}

Internal mechanisms are the internal means in the firm that can encourage managers to maximize the company value. These means include, in particular, board of directors, audit committees, auditor, ownership structure, mutual monitoring and supervisory board.

\section{(a) $\quad$ The board of directors}

The board of directors is one of the mechanisms of control that has been most discussed in research on corporate governance and the question of its usefulness has been much of debate over the last decade (Charreaux, 2000).

The board of directors, which represents the interests of shareholders, appears as the preferred mechanism responsible for controlling officers and whose function is essential to minimize the costs resulting from the separation of ownership and control in modern organizations. The board of directors controls the affairs of the company in order to achieve the following objectives:

- The verification of financial reliability;

- The verification of compliance with laws and regulations.

(b) Committees

Committees are subsidiary to the board of directors. They perform particular functions or the ones that are delegated by the board.

According to the legislation, committees are either mandatory or recommended. In some cases, they are required for companies well-defined in a sector. In countries where the creation of committees is mandated by laws or regulations, the number and structure of the committees are different from one country to another. Committees most commonly provided are: the audit committee; the remuneration committee...

(c) The auditor

The auditor represents a mechanism for management control and a way to reduce the discretionary latitude. The objective of the auditor is to provide shareholders with more developed and more relevant information. " The internal audit function plays a crucial role in the ongoing maintenance and assessment of a bank's internal control, risk management and governance systems and processes-areas in which supervisory authorities have a keen interest " (Basel Committee on Banking Supervision $\left.{ }^{2}, 2012\right)$. Also, both internal auditors and supervisors exploit risk based approaches to decide their respective work plans and actions.

(d) Structure-property: a means of controlling relations between Shareholders and managers

The ownership structure is an effective means of control of management executives, as it brings together, when certain conditions are present (capital concentration and nature of the shareholders), the basis for efficient monitoring system, namely, an incentive controllers to perform their functions, as well as cost control.

2 “The internal audit function in banks" This publication is available on the BIS website (www.bis.org) 
According to the agency theory two components of the ownership structure, the concentration of capital and the nature of the shareholders may be the cause of the performance of a company (Mtanios and Paquerot, 1999).

(2) External mechanisms

Besides the internal control mechanisms of the managers, there is another type of control that contributes to the regulation of potential conflicts that may arise between shareholders and managers. This control is exercised through the outdoor market including: financial market, market goods and services, labor market managers.

(a) The financial market

The control by the financial market, today, is more and more important with the development of stock markets. Indeed, there is a direct relationship between efficiency, competence of managers and market value of the company. If the management strategy is likely to harm the interests of shareholders, they always have the option to sell their shares, so, accordingly, decrease the value of the company. So, this mismanagement affects the value of the shares of the company and managers incur therefore the risk of being replaced after the takeover of a new investor.

\section{(b) The market of goods and services}

Competition in the market of goods and services can discourage leader of a firm who manage the detriment of shareholders. Indeed, any competitive market pushes the manager to optimize the management and to play a preventive role against the demise of the company. The effectiveness of this mechanism of control is limited.

(c) The labor market for managers

This market is an effective system of control since it highlights the importance of human capital in management. Managers are constantly faced with the pressure of the labor market. This place offers a selection of the most efficient of them through the competition which exists between external and internal managers.

\section{RESEARCH HYPOTHESES}

Governance has been recognized as one of the main research trends that affect all types of firms and banks in particular. Recall that our problem is to identify the mechanisms of government most commonly used in Tunisian banks.

This work therefore aims to test empirically the presence of certain corporate governance mechanisms in Tunisian banks. So, we test the following hypothesis:

Hypothesis 1: The mechanisms provided by the law (the board of directors, the auditors, the audit committee and the executive committee of credit) are charged by all Tunisian banks.

Hypothesis 2: The majority of Tunisian banks opt for independent board.

\section{SAMPLE AND METHODOLOGY OF RESEARCH}

For the purpose of the study, a sample of eight banks in 2006 was taken randomly from the list of Tunisian banks. Banks in the sample are:

* ATTIJARI BANK: limited liability company, with a capital of 150 million dinars

* AMEN BANK: limited liability company, with a capital of 70 million dinars.

* UIB: limited liability company, with a capital of 106 million dinars.

* ATB: limited liability company, with a capital of 60 million dinars.

* BIAT: limited liability company, with a capital of 170 million dinars.

- BH: limited liability company, with a capital of 75 million dinars.

- BT: limited liability company, with a capital of 50 million dinars.

* BTK: limited liability company, with a capital of 100 million dinars.

The study involved the analysis of annual reports of the banks stated above for the year 2006. We have manually collected such data from annual reports and the websites of these banks which were also consulted for specific issues such as relations with shareholders.

\section{RESULTS OF THE STUDY}

We present in the following paragraph the descriptive statistics of the study and we analyze afterward the results of the research.

1) Descriptive statistics

-Enumeration of governance mechanisms adopted by each bank in the sample:

For reasons of clarity, we firstly present the governance mechanisms of every bank in the sample. 
- Summary of governance mechanisms used by banks in the sample:

\begin{tabular}{|l|l|l|l|l|l|l|l|l|}
\hline & $\begin{array}{c}\text { Attijari } \\
\text { Bank }\end{array}$ & $\begin{array}{c}\text { Amen } \\
\text { Bank }\end{array}$ & UIB & ATB & BIAT & BH & BT & BTK \\
\hline The board of directors & $\checkmark$ & $\checkmark$ & $\checkmark$ & $\checkmark$ & $\checkmark$ & $\checkmark$ & $\checkmark$ & $\checkmark$ \\
\hline The Standing Committee on Audit & $\checkmark$ & $\checkmark$ & $\checkmark$ & $\checkmark$ & $\checkmark$ & $\checkmark$ & $\checkmark$ & $\checkmark$ \\
\hline The Compensation Committee & & & & & & & & \\
\hline The selection committee or appointment & & & & & & & & \\
\hline The Executive Committee of Credit & $\checkmark$ & $\checkmark$ & $\checkmark$ & $\checkmark$ & $\checkmark$ & $\checkmark$ & $\checkmark$ & $\checkmark$ \\
\hline Permanent body monitoring compliance & & $\checkmark$ & & & & $\checkmark$ & & \\
\hline Recovery Committee & & & & $\checkmark$ & & & & \\
\hline Classification Committee & & & & $\checkmark$ & & & & \\
\hline The Risk Committee & & & & & & $\checkmark$ & & \\
\hline The auditor & $\checkmark$ & $\checkmark$ & $\checkmark$ & $\checkmark$ & $\checkmark$ & $\checkmark$ & $\checkmark$ & $\checkmark$ \\
\hline The Supervisory Board & & & & & & & & \\
\hline Mutual monitoring & & & & & & & & \\
\hline The financial market & & & & & & $\checkmark$ & & $\checkmark$ \\
\hline The market for goods and services & & & & & & & & \\
\hline The labor market & & & & & & & & \\
\hline
\end{tabular}

To analyze the results of the study, it is necessary to translate the information indicated above statistical data in histograms which facilitates the reading of the results and makes it easier to identify characteristics of the system of governance of banks.

\section{Governance mechanisms used by banks in the sample}

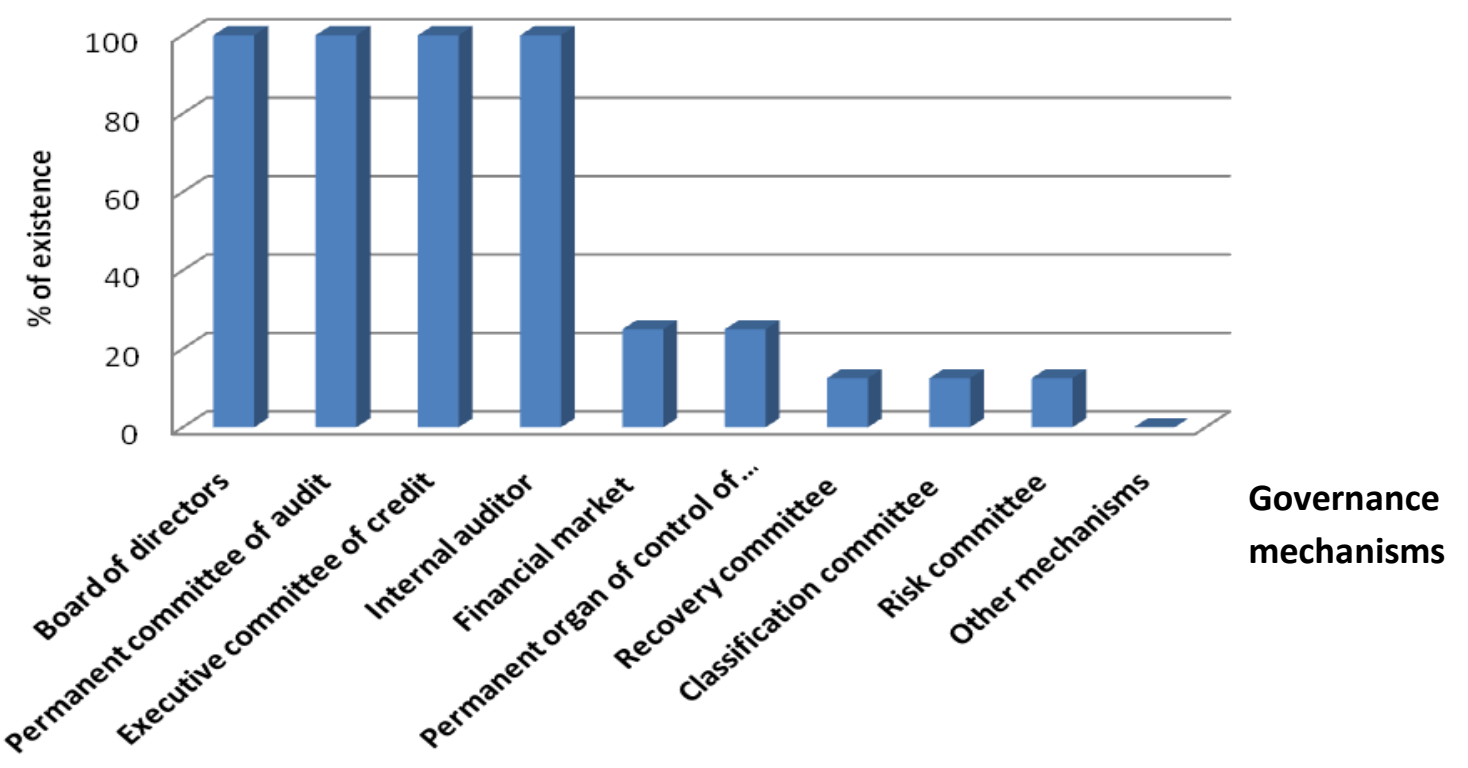

These findings need to be supplemented by other datas that have a direct influence on the government of the bank namely:

- The percentage of external members in the board of directors with respect to internal members

- The case of dual direction, where the president of the board is himself the chief executive officer (CEO)

- The size of the board of directors

These data provide a clear idea of the independence of the board and therefore the effectiveness of its governance. 
We present the results of our study about the independence of the boards in the following graph:

\section{Independance of boards of directors}

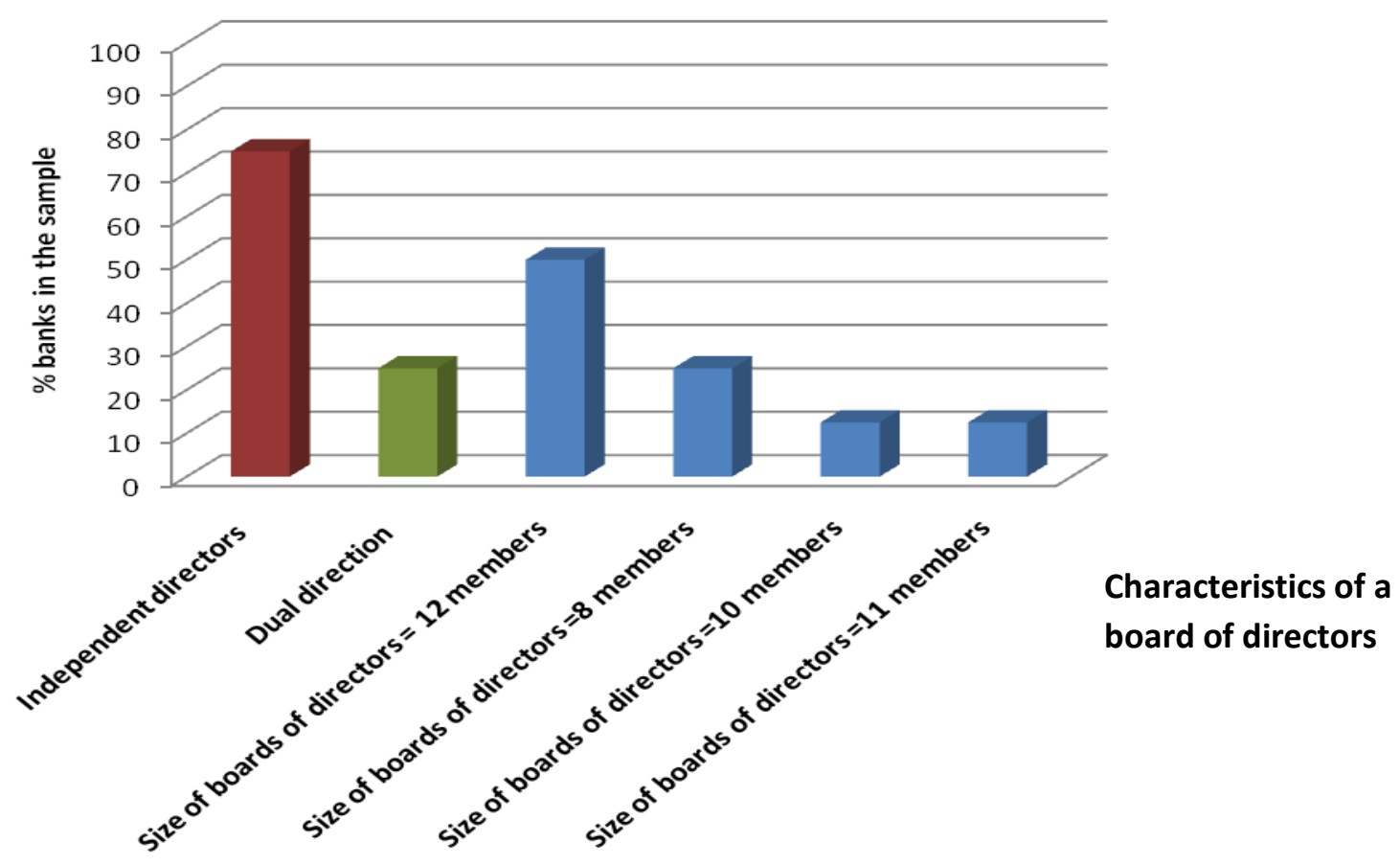

2) Analysis of results

The results of the study confirm the specificity and the particularity of the banking sector. Indeed, it is a highly regulated industry regarding the mechanisms of government. At these mechanisms, we must emphasize the importance of internal mechanisms compared to external ones. Among the internal mechanisms the board of directors remains the most important mechanism in the system of government. We can note precisely:

\section{- The multiplication of obligatory mechanisms}

If all the banks in the sample have a board of directors, a permanent audit committee, an executive committee and a credit auditor, it is not by chance or necessarily by conviction. Indeed, these mechanisms are obligatory in the banks (which confirm the hypothesis 1). Among these mechanisms, there are some ones that are not specific to banks (the board of directors and the auditor); others are specific to credit institutions (the executive credit committee). For example, the board of directors is governed by articles 189 to 223 of the commercial code of the companies promulgated by act $\mathrm{N}^{\circ}$. 2000-93 of 3 November 2000 promulgating the commercial code of companies. These items determine the composition, the appointment of members of the board, their rules and activities. Similarly, the commercial code of companies reserved items 258-273 for the auditor. We must add to these items the different accounting standards and circulars of the central bank. The law $\mathrm{n}^{\circ}$. 2001-65 of 10 July 2001 relative to the establishment of credit obliged, in the article 34, every credit institution to create a standing committee of internal audit. This obligation was generalized by article 256a of the commercial code of companies, which was added by law n ${ }^{\circ} 2005-96$ of 18 October 2005 that forced many firms to create a permanent audit committee.

But how the government can intervene to impose to a firm and more particularly to a bank governance mechanisms? Why the government does not trust the bank to make arrangements when it is necessary?

The indirect intervention of state in the governance of banks through regulations can be explained by a desire to ensure the stability of the financial system and protect the public interest. In fact, effective supervision of banking institutions is essential to give their central role in payment transactions, credit and bankruptcy propagation from one bank to all other banks, even performing ones (louizi, 2006).

\section{- Importance of internal mechanisms relative to external mechanisms.}

Consultation of banks' annual reports of the sample showed that there is almost no information about external governance mechanisms (with the exception of two banks that refers to the market). However, it does not mean the absence of any role of these mechanisms in the governance of the banks, this finding is only indicative of a fundamental reality in the banking sector, namely the importance of the internal governance relative to the external ones. According to Macey and O'Hara (2003), the discipline exerted by external 
mechanisms of governance is ineffective due to the high opacity. Louizi (2006) noted that banks are more obscure than other firms. Information asymmetry is omnipresent. It affects relationships between managers and board of directors in the bank. It also affects the relationship between these "internal" and shareholders. Similarly, it can affect the relationship between stakeholders and other partners of the bank in case the creditors, depositors and regulators. Other features of the banking sector may explain the preponderance of internal mechanisms for reporting to external mechanisms, for example:

- Competition in the services market is low at banks, given that managers establish barriers to access to information needed by developing networks of relationships with their customers (Levine, 2004).

- Competition among banks is limited by the shareholding of the State that holds significant shares in the capital of these banks and important shareholding of families which also prevents the entry of new competitors. Thus, foreign investors would be less willing to compete with local banks (Caprio and Levine, 2003).

- The efficiency of the stock market is also destabilized by the presence of the regulations and the high indebtedness of banks (Adams and Mehran, 2003).

\section{- The board of directors: the keystone of the governance system}

The board of directors is an important element of the governance system of banks. But the key for a bank (as well as for any business) is not the existence of the board, but rather its ability to accomplish its roles. This ability depends - as we said in the first part - on several factors, including its composition, size, presidency, executive compensation policy and policy of replacement of managers...

The annual reports of banks in the sample cannot verify the different criteria for evaluating the effectiveness of boards of directors seen as the lack of information about executive compensation and the policy of firing managers. We just evaluate the independence and effectiveness of boards of directors on the basis of their composition, their size and their presidency.

The composition of boards of directors, precisely the proportion of independent members is a measure of board effectiveness. Boards which have a majority of independent directors are considered more credible than others. This is the case in $75 \%$ of cases in the sample.

Concerning the size of the boards of banks, we note necessarily the large size of these boards. The article 189 of the commercial code of companies provides that the company should be administered by a board of directors composed of at least three members and maximum twelve members, our research revealed that $50 \%$ of them opted for the maximum number of board members namely 12 members, $12.5 \%$ of the banks have chosen a board of 10 members, $12.5 \%$ opted for a board of 11 members and $25 \%$ opted for a council of 8 members. In other words, the average number of members per board is almost 11 (10.6), while for firms in other sectors, in 2002 the average size is 7 members according to the study Zghal (2005) on 47 firms.

Finally, regarding the duality of direction: The board is considered independent when its president is not the CEO of the firm. Only $25 \%$ of banks have dual roles as president of the board of directors and CEO. So, there is a desire to make the control in banks more effective and rigorous which could be affected by the duality of direction.

We can conclude from all these characteristics of the boards of directors that Tunisian banks are increasingly opting for a more independent board (hypothesis 2 is verified), capable of protecting the interests of shareholders and discipline of managers.

- Utility of other corporate governance mechanisms

Even if the board was presented as the basis of the system of governance of banks, this does not diminish the role of other mechanisms. Two mechanisms have caught our attention, the first is the permanent audit committee and the second is the auditor.

- The permanent committee of internal audit, whose role was defined by section 34 of the law $n{ }^{\circ} 2001$ 65 of 10 July 2001 for credit institutions, became increasingly active. There is a growing awareness in some banks that internal control is one of the pillars of competitiveness. Therefore ATTIJARI BANK has developed in 2006 a new instruction manual of audit based in the risk approach. This manual has been finalized and approved by the direction on January 2007. The bank also undertook the reorganization of the general audit and the plan of the new internal control. The UIB implemented, since 2003, an audit empowering each level of the hierarchy and ensure that transactions are compliant with legal and regulatory requirements, professional practice, ethical rules and internal guidelines in the banks.

- The auditors of credit institutions, which must be members of the Institute of Chartered Accountants of Tunisia, are conducting a new special mission making them responsible for specific verifications required by law and professional standards.

\section{CONCLUSION}

The development of the theme of corporate governance is neither a trend nor the result of chance; it is totally linked to the evolution of modern business and the separation of ownership and decision. This issue does 
not only concern the shareholders and managers. Indeed, there is an awareness that corporate governance must be extended to all the relationships that managers have with stakeholders who are, for example, employees, suppliers, customers and shareholders...

It was necessary for us to begin our work by presenting the theoretical foundations of the concept "corporate governance", since we must understand the need to be able to provide the remedy. The need arises from conflicts between managers and stakeholders, especially shareholders. These conflicts caused negative consequences for the company. The appropriate remedy could be a system of governance consisting in internal mechanisms such as the board of directors, committees, the auditor, the supervisory board... and external mechanisms that are mainly the financial market, the market of goods and services and the labor market of managers. However, the existence of one or more of these mechanisms is not in itself a guarantee of efficiency. Accordingly, the effectiveness of the board depends on its size, its composition (external members / internal members) and its presidency (existence of dual direction: President of the board / CEO)...

Our descriptive study conducted on Tunisian banks, confirmed that most of the mechanisms used by the banks are the ones imposed by the laws and the regulations, all banks chosen in the sample have a board of directors, an auditor, a permanent audit committee and an executive committee. Credit Tunisian banks are increasingly opting for a more independent board of directors. Finally, we noted the importance of internal mechanisms versus external ones.

If the road to good governance seems drawn, the slope is still steep. Significant work remains to be done. We recommend the creation of other committees in the board of directors and the full transparency of its activity.

\section{REFERENCES}

[1] Pathan, S. and Skully M., 2010. Endogenously structured boards of directors in banks. Journal of Banking and Finance, 34(7), p 1590-1606.

[2] Louizi, G., 2006. Impact du conseil d'administration sur la performance des banques tunisiennes. XVème conférence internationale de management stratégique, Annecy/Genève 13-16 Juin 2006.

[3] Adams, R. and Mehran H., 2003. Board structure and banking firm performance and the bank holding company organizational form, Working Papers of Federal Reserve Bank of Chicago, 2003, 408-422.

[4] Caprio, G., Laeven, L., \& Levine R., 2007. Governance and bank valuation. Journal of Financial Intermediation, 16, 584-617.

[5] Rachdi, H. and Ghazouani Ben ameur, I. 2011. Board Characteristics, Performance and Risk Taking Behavior in Tunisian Banks. International Journal of Business and Management, 6 (6) p. 88-97.

[6] Erkens, D. H., Hung, M. and Matos, P. 2012. Corporate governance in the 2007-2008 financial crisis: Evidence from financial institutions worldwide. Journal of Corporate Finance 18 (2012), p 389-411.

[7] Stiglitz J.E. and Edlin A.S., 1992. Discouraging rivals, managerial rent seeking and economic insufficiencies. NBER Working Paper, No.4145, August.

[8] Morck R., Schleifer A. and Vishny R.W. 1990. Do managerial objectives drive bad acquisitions? , Journal of Finance, n ${ }^{\circ 5}$, p.3148.

[9] Fransman M. 1998. Information, Knowledge, Vision and Theories of the Firm. in G. Dosi, D.J. Teece et J. Chitry, Technology, Organization and Competitiveness- Perspectives on Industrial and Corporate Change, Oxford University Press, p. $147-191$.

[10] Charreaux G., 2002. A la recherche de nouvelles fondations pour la finance et la gouvernance d'entreprise. Finance Contrôle Stratégie, Vol 5, N³, September 2002, p. 5-68.

[11] Rabin M., 2002. A Perspective on psychology and economics. European Economic Review, vol. 46, 2002, p. 657-685.

[12] Albouy M. et Charreaux G., 2005. La Finance comportementale ou l'émergence d'un nouveau paradigme dominant ?, Revue française de gestion 2005/4, n 157 , p. 139-143.

[13] Charreaux G., 2005. Pour une gouvernance d'entreprise comportementale. Une réflexion exploratoire.... Revue française de gestion 2005 /4, n157, p.215-238.

[14] Ulen T. 1998. The Growing Pains of Behavioral Law and Economics. The Growing Pains of Behavioral Law and Economics, Vanderbilt Law Review, vol. 51, p. 1747-1763.

[15] Aoki M., 2000. Information Corporate Governance and Institutional Diversity: competitiveness in Japan, the USA, and the transitional economies, NEWYORK: Oxford University Press.

[16] Charreaux G., 1996. Vers une théorie du gouvernement des entreprises. Working paper.

[17] Zingales L., 2000. In Search of New Foundations. The journal of finance. Vol. LV, N. 4 • august 2000, p 1623-1653.

[18] Charreaux G., 2000. Le conseil d'administration dans les théories de la gouvernance. Revue du Financier, 127, p. 6-17.

[19] Mtanios R. et Paquerot M., 1999. Structure de propriété et sous performance des firmes : une étude empirique sur le marché au comptant, le règlement mensuel et le second marché. Finance Contrôle Stratégie, Volume 2, N4, p.157-179.

[20] Tunisian commercial code 2006

[21] Macey J.R. et O'Hara M. 2003. The Corporate Governance of Banks. Economic Policy Review, Federal Reserve Bank of New York, Special Issue, Vol 9, $\mathrm{N}^{\circ} 1$, Avril.

[22] Levine R. 2004. The corporate governance of banks. A concise discussion of concepts and evidence. World Bank Policy Research Working Paper, ${ }^{\circ} 3404$, September 2004.

[23] Adams, R. and Mehran, H. 2003. Is corporate governance different for Bank Holding Companies? .FRBNY Economic Policy Review / April 2003, p123-142.

[24] Caprio, G.Jr. and Levine R. 2003. Corporate governance of banks: Concepts and international observations. Global Corporate Governance Forum 1818 H Street, NW, Washington DC, 20433 USA.

[25] Zeghal, Daniel M. et al. 2005. Impact de la structure de propriété et de l'endettement sur les caractéristiques du conseil d'administration : Etude empirique dans le contexte tunisien, 3rd International Finance Conference, IFC3, Association Française de Finance (AFFI). 